\section{NADPH-d activity in rat thymus after the application of retinoid acid}

\author{
F. Dorko, ${ }^{1,2}$ T. Špakovská, ${ }^{1}$ K. Lovasová, ${ }^{1}$ \\ P. Patlevič, ${ }^{2}$ D. Kluchová1 \\ 'Department of Anatomy, Faculty of \\ Medicine, Pavol Jozef Šafárik University \\ in Košice, Slovakia; \\ 2Department of Anatomy, Faculty of \\ Medicine, University of Ostrava, \\ Czech Republic
}

\begin{abstract}
The aim of this work was to determine the localization of nicotinamide-adenine dinucleotide phosphate-diaphorase (NADPH-d) activity as the marker for synthesis of nitric oxide synthase (NOS) in the rat thymus after the application of retinoid acid (RA) on $1^{\text {st }}, 7^{\text {th }}$, $14^{\text {th }}$ and $21^{\text {st }}$ days of gestation. The given results can build the basis for understanding of the role of NOS in rat thymus. NADPH-d positive cells were represented with dark-blue color and were localized on corticomedullar junction of the thymus. These cells were of different intensity of coloring and were shaped in oval, circle or irregular forms. NADPH-d positive nerve fibers were observed in perivascular topography. They were marked more strongly in the case of control group. The result of application of RA to gravid rats was that the birth weights of newborn rats and their thymuses were smaller, but without statistically significance.
\end{abstract}

\section{Introduction}

Vitamins play a great role in the nourishment. Vitamin A is one of the basic nutritive factors that are important for the development of a fetus. It is also important for the differentiation of cells in the organism., ${ }^{1,2}$ This vitamin belongs to the group of vitamins that are fatsoluble. It was discovered by George Wald in 1927. Hale discovered the importance of this vitamin as an essential source for the fetus development in $1933,{ }^{3}$ but later on it was discovered that it also has teratogenic effect. ${ }^{4}$

Vitamin A belongs to terpenoids. Natural or synthetic derivatives of vitamin A are called retinoids. Their total number is estimated to $2500 .^{5}$ Biologically most active retinoid is retinoid acid (RA), which is used in clinical medicine. It is used in treatment of dermal and hematological diseases and in prevention of secondary tumors of head and neck. All-trans RA are a derivate of vitamin A. It is essential in the case of gene expulsion that is mediated by two groups of nuclear receptors: RAR (retinoic acid receptor) and RXR (retinoid X receptor). ${ }^{6,7}$ Retinoids are important molecules involved in the development and homeostasis of the nervous system. RA influences development and differentiation of cells. Its teratogenic effect is caused by excessive consumption of RA. The teratogenic effect differs with species, concentration and form of application of RA to gravid female. ${ }^{8}$

It is therefore important to know that daily limit of vitamin A is $1500 \mathrm{RE}$ (RE, retinol equivalent) for adults and $2400 \mathrm{RE}$ for women in the time of gravidity and lactation $(1 \mathrm{RE}=1$ $\mu \mathrm{g}$ retinol=3.3U). The daily limit of vitamin A for a gravid woman should not exceed 2800$3000 \mathrm{RE} /$ day. Vitamin A can cause chronic toxicity by adults when it is received in overdose 7500-9000 RE/day for a long period of time on regular basis. ${ }^{9}$ The excess of vitamin $\mathrm{A}$ in the nourishment is teratogenic in the development of hearth, aortic arch, limbs, thymus and central nervous system. When studying the influence of RA on the organism some changes are observed in neurotransmitters like acetylcholine and nitric oxide (NO). NO is small electrically neutral molecule of gaseous character that has a short half-life and can defund through biological membranes of cells. Enzyme neuron synthesis of NO (nNOS) participates on the synthesis of NO. NO as a signal molecule can have positive contribution to the organism but if it is overproduced it can contribute to the cell damage strongly. ${ }^{10} \mathrm{We}$ used the immunohistochemical method and NADPH-d histochemical method that enables the visualization of nNOS, to prove the presence of NO. Localization of nicotinamide-adenine dinucleotide phosphate-diaphorase (NADPH-d), that was observed histochemically, was described for the first time on a rat where it confirmed the presence of dark-blue reactionary product.

\section{Materials and Methods}

There were used primipara females of Wistar rats with the weights of 220-250 grams. The animals were bred in standard laboratory conditions: room temperature $20-22^{\circ} \mathrm{C}$, free access to food and water. Females were coupling with three-month-old Wistar rat males. The day of positive vaginal epithelium smear was marked as the first day of gravidity. We gave all-trans retinoic acid (RA) to gravid females in the amount of $10 \mathrm{mg} / \mathrm{kg}$ of weight. They received the RA per orally dissolved in sesame oil for three days that means eight,
Correspondence: Prof. František Dorko, Department of Anatomy, Faculty of Medicine, Pavol Jozef Šafárik University in Košice, Šrobárova Street 2, 04180 Košice, Slovakia.

Tel. +421.55.6428151.

E-mail: frantisek.dorko@upjs.sk

Key words: nicotinamide-adenine dinucleotide phosphate-diaphorase, nitric oxide, retinoid acid, rat, thymus.

Acknowledgement: the study was supported by the Grant VEGA of Ministry of Education of Slovakia No.1/0643/08.

Received for publication: 19 November 2011.

Accepted for publication: 16 January 2012.

This work is licensed under a Creative Commons Attribution NonCommercial 3.0 License (CC BYNC 3.0).

(C) Copyright F. Dorko et al., 2012

Licensee PAGEPress, Italy

European Journal of Histochemistry 2012; 56:e7 doi:10.4081/ejh.2012.e7

ninth and tenth day of gestation. In the postnatal period we observed NADPH-d nervous structures in thymus on the first, seventh, fourteenth and twenty-first days of newborn rats. We recorded the weight of rats and their thymuses.

The newborn rats on $1^{\text {st }}, 7^{\text {th }}, 14^{\text {th }}$ and $21^{\text {st }}$ day (in each day 10 experimental animal after prenatal administration of retinoid acid and 5 control) were anesthetized with pentobarbital and killed by intracardial perfusion of $4 \%$ paraformaldehyde containing $0.1 \%$ glutaraldehyde in $0.1 \mathrm{M}$ phosphate buffer of $\mathrm{pH}$ 7.4. Solutions were prepared immediately before perfusion. After stored perfusion, the thymuses were removed surgically and stored in identical fixative solution for 3-4 hours. Then they were transferred to $30 \%$ sacharose solution in the same phosphate buffer and stored over night at $4^{\circ} \mathrm{C}$. Sections $(45 \mu \mathrm{m})$ from the excisions were prepared by means of a cryo-microtome.

A histochemical reaction modified according to Scherer-Singler et al. (1983) ${ }^{11}$ was used to visualize NADPH-d activity. The sections were incubated in a solution of $1.5 \mathrm{mM}$ tetrazolium nitroblue (NBT, Sigma Chemicals, St. Louis, MI, USA), $1.0 \mathrm{mM}$ beta nicotinamide adenine dinucleotide phosphate (NADPH, Sigma Chemicals), $10.0 \mathrm{mM}$ monosodium maleate (maleic acid, Sigma Chemicals) and 0.5 Triton X-100, dissolved in $0.1 \mathrm{M}$ phosphate buffer, $\mathrm{pH} 8.0$, at $37^{\circ} \mathrm{C}$ for $1 \mathrm{~h}$. After incubation, the sections were washed with $0.1 \mathrm{M}$ phosphate buffer ( $\mathrm{pH} 7.4$ ), mounted in Entellan and evaluated under a light microscope.

All experiments were conducted in accor- 
dance with European Directive for the Protection of Vertebrate Animals Used for Experimental and Other Scientific Purposes (86/609/EU) and approved by the State Veterinary and Food Administration of Slovak Republic by decision 1696/07-221a.

The statistical analysis between birth weights of rats with/without prenatal application of retinoid acid as well of rat's thymuses with/without prenatal application of retinoid acid was tested with Student $t$-test. Statistical significance was set at the level of significance $\mathrm{P}<0.05$. Software Statistical Package for the Social Sciences (SPSS) for Windows version 13.0 was used for all statistical calculations.

\section{Results}

We proved that NADPH-d positive cells and nerve fibers were present in the rat thymus. NADPH-d positive cells, marked in dark-blue coloring, were mostly present in the thymic medulla and in corticomedullar junction, and only a small dispersion was detectable in the cortex. The individual nerve cells were irregularly shaped with different intensity of color. Cells that had the lowest rate of NADPH-d positivity were weakly colored and only the edge of their bodies is seen. These cells were dispersed throughout the whole medulla. A group of cells in the medulla had a strong intensity of coloring. Small processes were observed on these dark blue cells. This type of cells appeared near the vessels of the thymus medulla. Blood vessels localized in the medulla and interlobular septa showed NADPH-d positivity of endothelial cells. NADPH-d positive nerve fibers were observed in perivascular topography in $1^{\text {st }}, 7^{\text {th }}, 14^{\text {th }}$ and $21^{\text {st }}$ day. The density of these fibers increased with age. The irregular NADPH-d positive cells were mostly observed soon after delivery. In cases of experimental animals - after prenatal application of retinoid acid, the intensity of NADPH-d positive nerve fibers were decreased regardless of the day after delivery (Figures 1, 2, 3, 4, 5 and $6)$. The application of retinoic acid in the amount of $10 \mathrm{mg} \mathrm{RA} / \mathrm{kg}$ of weight applied on $8^{\text {th }}, 9^{\text {th }}$ and $10^{\text {th }}$ day of gravidity caused also the decrease of the rat birth weight and it caused the decrease of the weight of thymuses. However, these changes were not statistically significant (with exception of body weight in day 7; Table 1).

\section{Discussion}

Thymus is one of the most mysterious organs. The term thymus was introduced in

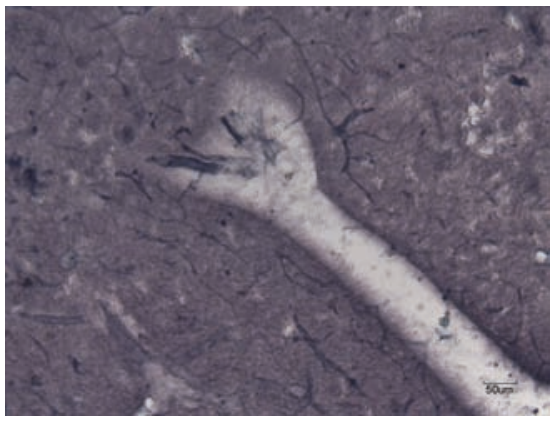

Figure 1. Experimental group: newborn rats thymus after prenatal application of retinoid acid (1st day after delivery). NADPH-d positive nerve fibers are weakly marked in perivascular topography. No cell bodies were observed.

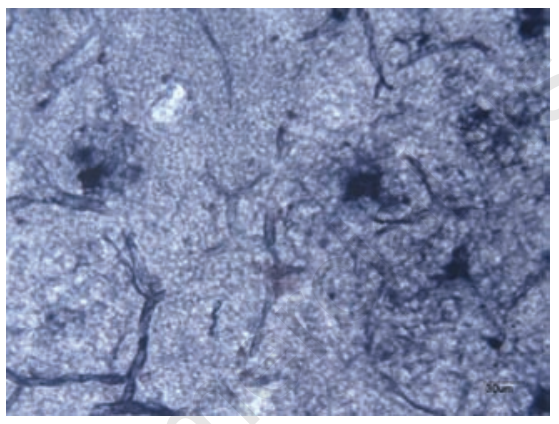

Figure 2. Control group: newborn rats thymus without prenatal application of retinoid acid ( $1^{\text {st }}$ day after delivery). Irregularly shaped cells with deeply blue colored protuberances localized in the thymic medulla.

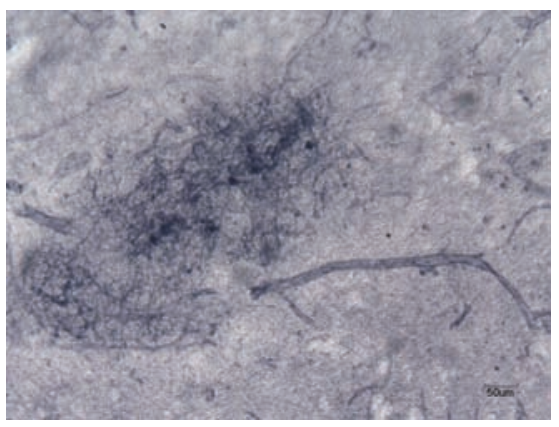

Figure 3. Experimental group: newborn rats thymus after prenatal application of retinoid acid $\left(\mathbf{1 4}^{\text {th }}\right.$ day after delivery). Rich represented NADPH-d positive cells on the corticomedullar junction. The presence of NADPH-d positive neural fibers in perivascular topography was observed.
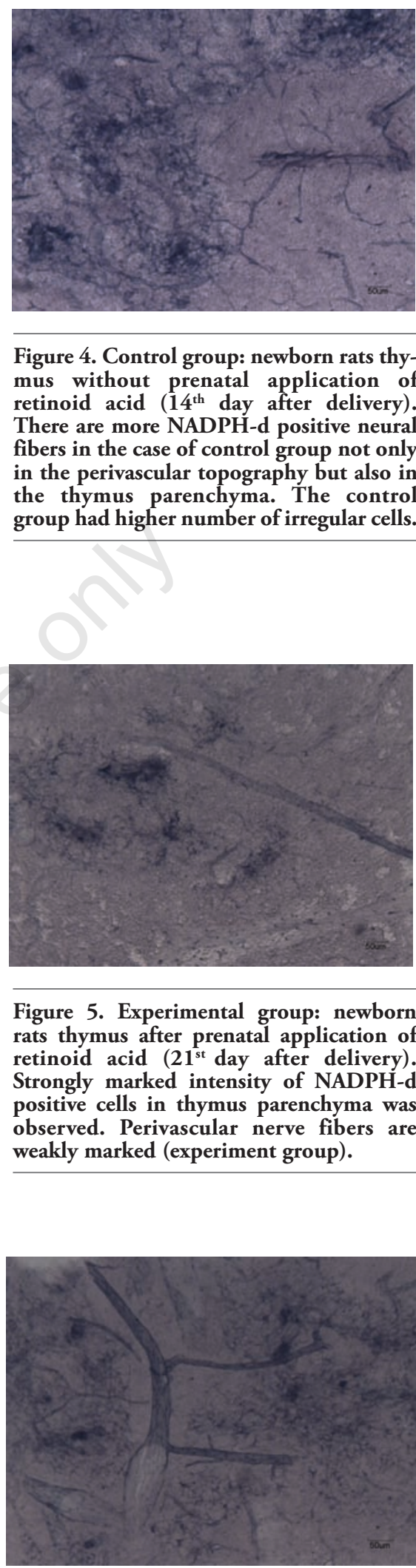

Figure 4. Control group: newborn rats thymus without prenatal application of retinoid acid (14 $4^{\text {th }}$ day after delivery). There are more NADPH-d positive neural fibers in the case of control group not only in the perivascular topography but also in the thymus parenchyma. The control group had higher number of irregular cells.

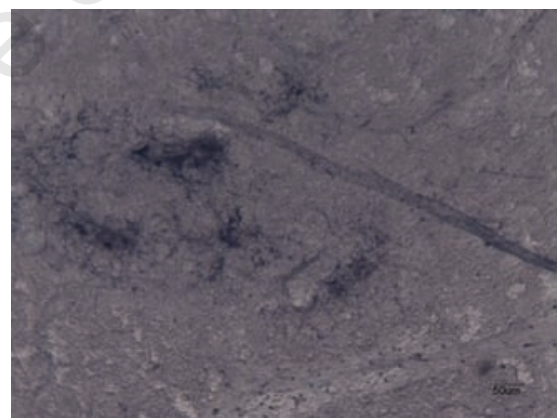

Figure 5. Experimental group: newborn rats thymus after prenatal application of retinoid acid ( $21^{\text {st }}$ day after delivery). Strongly marked intensity of NADPH-d positive cells in thymus parenchyma was observed. Perivascular nerve fibers are weakly marked (experiment group).

Figure 6. Control group: newborn rats thymus without prenatal application of retinoid acid $\left(21^{\text {st }}\right.$ day after delivery). Strongly marked NADPH-d nerve fibers in perivascular topography and in thymic connective tissue septum. 
Table 1. Effects of the application of retinoic acid on rats and thymuses weight.

\begin{tabular}{|c|c|c|c|}
\hline & $\begin{array}{l}\text { Experimental group } \\
(\text { Mean } \pm \text { SD) }\end{array}$ & $\begin{array}{l}\text { Control group } \\
\text { (Mean } \pm \text { SD) }\end{array}$ & Level of significance \\
\hline $\begin{array}{l}\text { One-day-old-rats } \\
\text { Weight of the rats (g) } \\
\text { Weight of thymuses (g) }\end{array}$ & $\begin{array}{l}5.90 \pm 1.04 \\
0.07 \pm 0.05\end{array}$ & $\begin{array}{l}7.15 \pm 0.84 \\
0.06 \pm 0.02\end{array}$ & $\begin{array}{l}\mathrm{P}=0.054 \mathrm{~ns} \\
\mathrm{P}=0.271 \mathrm{~ns}\end{array}$ \\
\hline $\begin{array}{l}\text { Seven-day-old rats } \\
\text { Weight of the rats }(\mathrm{g}) \\
\text { Weight of thymuses }(\mathrm{g})\end{array}$ & $\begin{array}{r}12.94 \pm 2.63 \\
0.07 \pm 0.02\end{array}$ & $\begin{array}{r}16.38 \pm 0.83 \\
0.09 \pm 0.02\end{array}$ & $\begin{array}{l}\mathrm{P}=0.016^{*} \\
\mathrm{P}=0.093 \mathrm{~ns}\end{array}$ \\
\hline $\begin{array}{l}\text { Fourteen-day-old rats } \\
\text { Weight of the rats (g) } \\
\text { Weight of thymuses (g) }\end{array}$ & $\begin{array}{r}29.37 \pm 6.60 \\
0.14 \pm 0.06\end{array}$ & $\begin{array}{r}30.67 \pm 6.49 \\
0.18 \pm 0.05\end{array}$ & $\begin{array}{l}\mathrm{P}=0.714 \mathrm{~ns} \\
\mathrm{P}=0.175 \mathrm{~ns}\end{array}$ \\
\hline $\begin{array}{l}\text { Twenty-one-day-old rats } \\
\text { Weight of the rats (g) } \\
\text { Weight of thymuses (g) }\end{array}$ & $\begin{array}{c}48.19 \pm 14.85 \\
0.31 \pm 0.10\end{array}$ & $\begin{array}{r}53.59 \pm 4.63 \\
0.35 \pm 0.04\end{array}$ & $\begin{array}{l}\mathrm{P}=0.337 \mathrm{~ns} \\
\mathrm{P}=0.396 \mathrm{~ns}\end{array}$ \\
\hline
\end{tabular}

SD, standard deviation; ns, not significant; *significant.

anatomy by Claudius Galenos of Pergamon in the second century AD. ${ }^{12}$ The thymus is a primary lymphoid organ that is found in all vertebrates, with the exception of jawless fish..$^{13}$ The thymus has a unique capacity to support the development of self-tolerant T cells expressing a diverse repertoire of antigen receptors.

The embryonic pharynx serves as the origin of the mammalian thymus. The thymic primordia are formed from the dorsolateral portions of the third paired pharyngeal pouches. In absence of the cell-to-cell interactions with the ectomesenchyme (neural crest cells), the primary epithelial anlagen are unable to proliferate. Thymic organogenesis depends on the interactions between the cells of all three embryonic germ layers: endoderm-derived epithelium of pharyngeal pouches, neuroectoderm-derived neural crest mesenchyme and mesoderm-derived hematopoietic cells Thymopoiesis involves reciprocal tissue interactions between the epithelial cells derived from the endoderm of the embryonic pharynx and neural crest-derived mesenchyme. ${ }^{14,15}$ Thymus undergoes its maximum development in the time of birth, when it also has the greatest relative weight. Its morphology varies greatly even in the same age group. These anatomic variations and dynamic changes appear to be the main source of confusion with pathologic conditions. ${ }^{16-18}$ After the puberty the thymus becomes smaller and the portion of adipose connective tissue grows at the expense of lymphatic tissue. The factors that influence the size of the thymus are age, stress, infections, hormonal treatment and undernutrition. ${ }^{19}$

The innervations of thymus is not completely known, many authors are focused on the neural structures localized inside the thymus. ${ }^{20-22}$ The aim of our work was observed the histochemical representation of NADPH-d positive cells and nerve fibers in rat thymus after prenatal application of retinoid acid. NADPH-d can be considered as a mark of NOS, enzyme responsible for synthesis. ${ }^{23,24}$ The activity of this enzyme was proved in many parts of nervous system in mammals..$^{25}$ Our results are in agreement with other authors, who also confirmed that NADPH-d positive cells are present in the rat thymus. ${ }^{26-28}$ The observation of the thymus after the application of retinoid acid confirms the resemblance of NADPH-positive cells described by Gulati et al. ${ }^{27}$ In a further study, the same authors studied these cells at the electron-microscopic level. ${ }^{29}$

We observed NADPH-d positive nerve fibers in the perivascular topography. In the experiment group of rats, to which the all-trans RA was applied were these structures less marked. By observing NADPH-d neural structures we did not observe the cell bodies of neurons in thymuses. The interference of fibers in the perivascular topography allow to assume that NO is able to participate on neurotransmission in thymus. In the same way there was proved the NADPH-d positive colored bodies of nerve cells and nerve fibers.

Our observation proved that the application of RA on $7^{\text {th }}, 8^{\text {th }}$ and $9^{\text {th }}$ day of gestation influenced the weight of new-born rats and the thymus size, too. Our observations are in agreement with other authors that retinoid acid can disrupt development of nervous system..$^{30-33}$

\section{References}

1. DeLuca LM, Darwiche N, Jones CS, Scita G. Retinoids in differentiation and neoplasia. Sci Am Sci Med 1995;2:28-37.

2. Zile MH. Vitamin A and embryonal development. J Nutr 1998;128:4555-85.

3. Hale F. Pigs born without eyeballs. J Heredit 1933;24:105-06.

4. Cohlan SQ. Excessive intake of vitamin A as a cause of congenital anomalies in the rat. Science 1953;117:535-36.

5. Velíšek J, Hajšlová V. Chemie potravin [Article in Czech]. Tabor 2009.

6. Azais-Braesco V, Pascal G. Vitamin A in pregnancy: requirements and safety limits. Am J Clin Nutr 2000;71:1325-33.

7. Martinez-Angoa A, Parra-Hernandez E, Madrigal-Bujaidar E. Reduction of alltrans-retinoic acid-induced teratogenesis in the rat by glycine administration. Birth Defects Res A Clin Mol Teratol 2006;76: 731-8.

8. Veiga Quemelo PR, Marques Lourenco Ch, Peres LC. Teratogenic effect of retinoic acid in swiss mice. Acta Chir Brasil 2007;22:451-6.

9. Bender DA. Nutritional biochemistry of the vitamins. 2003, Cambridge University Press, Edinburgh, UK.

10. Brown GC. Nitric oxide and neuronal death. Nitric Oxide 2010;23:153-65.

11. Scherer-Singler U, Vincent SR, Kimura H, McGeer EG. Demonstration of a unique population of neurons with NADPHdiaphorase histochemistry. J Neurosci Meth 1983;9:229-34.

12. Kachlik D, Baca V, Bozdechova I, Cech P, Musil V. Anatomical terminology and nomenclature: past, present and highlights. Surg Radiol Anat 2008;30:459-66.

13. Varga I, Pospíšilová V, Gmitterová K, Gálfiová P, Polák Š, Galbavý Š. The phylogenesis and ontogenesis of the human pharyngeal region focused on the thymus, parathyroid, and thyroid glands. Neuro Endocrinol Lett 2008;29:837-45.

14. Varga I, Pospisilova V, JablonskaMestanova V, Galfiova P, Polak S. The thymus: Picture review of human thymus prenatal development. Bratisl Lek Listy 2011;112:368-76.

15. Varga I, Pospisilova V, Jablonska V, Sisovsky V, Galfiova P, Polak S, et al. Thymic Hassall's bodies of children with congenital heart defects. Bratisl Lek Listy 2010;111:552-7.

16. Bodey B, Bodey B Jr, Siegel S, Keiser HE. Involution of the mammalian thymus, one of the leading regulators of aging. In Vivo 1997;11:421-40.

17. Varga I, Uhrinova A, Toth F, Mistinova J. Assessment of the thymic morphometry using ultrasound in full-term newborns. Surg Radiol Anat 2011;33:689-95.

18. Varga I, Tóth F, Uhrinová A, Neščáková E, Polák S. Association among size of thymus, anthropometric dimensions and number of lymphocytes in peripheral blood in newborns from Slovakia. Biomed Pap Med Fac Univ Palacky Olomouc Czech Repub 2009;153:229-34.

19. Varga I, Nescakova E, Toth F, Uhrinova A, 
Adamkov M. Nutrition and immune system: the size of the thymus as an indicator of the newborn's nutrition status. Anthrop Anz 2011;68:265-74.

20. Mignini F, Sabbatini M, D'Andrea V, Cavallotti C. Intrinsic innervation and dopaminergic markers after experimental denervation in rat thymus. Eur J Histochem 2010;54:e17.

21. Dorko F, Danko J, Flešárová $S$, Boroš $E$, Sobeková A. Effect of pesticide bendiocarbamate on distribution of acetylcholineand butyrylcholine-positive nerves in rabbit's thymus. Eur J Histochem 2011;55:e37.

22. Mojžišová J, Šulla I. Vplyv pesticídov na imunitný system zvierat [Influence of pesticides on immune system of animals]. Pages 67-75 in: J Danko, F Lešník, A Jenča (eds). Xenobiotiká vo vz ahu k zdraviu [Xenobiotics in relationship to health]. University of Veterinary Medicine, Košice, Slovakia, 2005.

23. Bredt DS. Nitric oxide signaling specificity - the heart of the problem. J Cell Sci 2003;116:9-15.
24. Schmidt HH, Gagne GD, Nakane M, Pollock JS, Miller MF, Murad F. Mapping of neural NO synthase in the rat suggests frequent localization with NADPH diaphorase but not soluble guanylyl cyclase and novel paraneural functions for nitrinergic signal transduction. J Histochem Cytochem 1992; 40:1439-56.

25. Anderson CR, NADPH diaphorase-positive neurons in the rat spinal cord include a subpopulation of autonomic preganglianic neurons. Neurosci Lett 1992;139:280-84.

26. Downing JEG. Multiple nitric oxide synthase systems in adult rat thymus revealed using NADPH diaphorase histochemistry. Immunology 1994;82:659-64.

27. Gulati P, Chan AS, Leong SK. NADPHdiaphorase positive cell in the chick and rat thymus. Thymus 1993;22:117-24.

28. Danko J, Ondrašovič M, Švický E, Jenča A, Oipieszny $\mathrm{N}$, Ondrašovičová 0 . Histo chemical study of innervation and NADPHD activity of the thymus. Anat Histol Embryol 2003;32:233-5.

29. Gulati P, Chan AS, Leong SK. Ultrastru- ctural localisation of NADPH-diaphorase in the chick thymic medulla. Cell Tissue Res 1995;279:405-9.

30. Bolekova A. Retinoic acid and cholinergic neurons in the rat spinal cord. Folia Medica Cassoviensia 2010;2:39-43.

31. Christie VB, Maltman DJ, Henderson AP, Whiting A, Marder TB, Lako M, et al. Retinoid supplementation of differentiating human neural progenitors and embryonic stem cells leads to enhanced neurogenesis in vitro. J Neurosci Meth 2010;193: 239-45.

32. Engberg N, Kahn M, Petersen DR, Hansson M, Serup P. Retinoic acid synthesis promotes development of neural progenitors from mouse embryonic stem cells by suppressing endogenous, Wnt-dependent nodal signaling. Stem Cells 2010;28: 1498-509.

33. Estephane D, Anctil M. Retinoic acid and nitric oxide promote cell proliferation and differentially induce neuronal differentiation in vitro in the cnidarian Renilla koellikeri. Dev Neurobiol 2010;70:842-52. 